\title{
Inhibition of Bovine Endothelial Cell Activation In Vitro by Regulated Expression of a Transdominant Inhibitor of NF-kB
}

\author{
Josef Anrather, Vilmos Csizmadia, Christine Brostjan, Miguel P. Soares, Fritz H. Bach, and Hans Winkler
}

Sandoz Center for Immunobiology, Deaconess Hospital, Harvard Medical School, Boston, Massachusetts 02215

\begin{abstract}
The activation of endothelial cells is a recurrent phenomenon linked to pathologic conditions such as inflammation, chronic arthritis, allo- and xenograft rejection. To inhibit endothelial cell activation we have constructed a transactivation-deficient derivative of the p65/RelA subunit of NF- $\mathrm{B}$, a transcription factor known to be crucial for the induction of adhesion molecules, cytokines and procoagulants in activated endothelial cells. This protein (p65RHD) comprises the Rel homology domain of the RelA subunit, retaining dimerization, DNA binding, and nuclear localization functions, but is deficient in transcriptional activation, and acts as a competitive inhibitor of NF-кB. Our data demonstrate that p65RHD is a potent and specific inhibitor of NF- $\kappa \mathrm{B}-$ mediated induction of a number of genes, such as $\mathrm{I} \kappa \mathrm{B} \alpha$, IL-8, E-selectin, P-selectin, and tissue factor in endothelial cells. Furthermore, tetracycline-inducible expression of p65RHD in stably transfected primary endothelial cells inhibits the induction of gene expression equally well. This regulated system of gene expression provides the basis for a novel therapeutic approach to the pathologic effects of endothelial cell activation, especially in delayed xenograft rejection, by using transgenic animals as organ donors. (J. Clin. Invest. 1997. 99:763-772.) Key words: tetracycline regulation • stable transfection - endothelial cells • adhesion molecules $\bullet$ NF- $\mathrm{B}$
\end{abstract}

\section{Introduction}

The vascular endothelium in its quiescent state performs a number of critical functions, including maintaining anti-coagulation, and providing a selective barrier to the trafficking of cellular and soluble blood components. The endothelial cell phenotype is changed significantly upon stimulation with cytokines (e.g., IL-1, TNF $\alpha$ ) or LPS in vitro as well as in vivo at sites of acute and chronic inflammation such as arthritis or in allo- and xenograft rejection. These phenotypic changes, referred to as endothelial cell activation, are accompanied by transcriptional induction of a number of pro-inflammatory genes, including adhesion molecules such as E-selectin, $P$ - selec-

Address correspondence to Dr. Hans Winkler, Sandoz Center for Immunobiology, 99 Brookline Ave., Boston, MA 02215. Phone: (617) 632-0885; FAX: (617) 632-0880; E-mail: hwinkler@bidmc.har vard.edu

Received for publication 1 August 1996 and accepted in revised form 5 December 1996.

J. Clin. Invest.

(C) The American Society for Clinical Investigation, Inc.

0021-9738/97/02/0763/10 \$2.00

Volume 99, Number 4, February 1997, 763-772 tin, $V C A M-1$, and $I C A M-1$, and proinflammatory cytokines and chemokines such as $I L-1, I L-6, I L-8$, and $M C P-1$ (1-6). Moreover, endothelial cell activation also leads to the up-regulation of pro-thrombotic genes including tissue factor (7), the central initiator of coagulation and thrombosis in xenograft rejection (8).

Sequence comparison of the regulatory regions of genes induced during endothelial cell activation reveals a remarkable common feature: essentially all of them contain at least one binding site for the transcription factor NF-кB (9-22). It has been shown by deletion mutagenesis and reporter gene analysis that NF- $\mathrm{KB}$ is essential in the transcriptional induction of these genes (9-22). In quiescent endothelial cells, NF-kB (e.g., the NF- $\mathrm{BB} 1$ [p50]/RelA [p65] heterodimer) is retained in the cytoplasm by association with IкB (inhibitor of NF-кB) proteins. After cell stimulation, IкB is phosphorylated (23-30), ubiquitinated (31-36) and degraded (37-40), releasing NF-кB from these trimeric complexes, and allowing NF- $\mathrm{BB}$ translocation to the nucleus. The most abundant form of $N F-\kappa B$ in endothelial cells is the NF-кB1/RelA heterodimer. Of these two, RelA contributes primarily to transcriptional activation, whereas NF- $\mathrm{B} 1$ is mainly involved in DNA binding (although DNA context-dependent transactivating functions of NF- $\mathrm{B} 1$ in vitro have been described, either per se [41, 42], or mediated by Bcl-3 [43]). Bcl-3 has also been shown to stabilize NF- $\mathrm{B} 1$ homodimers in transgenic mice constitutively expressing Bcl-3 in the thymus (44).

The NF-кB/Rel family of proteins share a highly homologous sequence of approximately 300 amino acids, referred to as the Rel homology domain (RHD). ${ }^{1}$ The RHD contains sequences necessary for DNA binding, nuclear localization, dimerization, and IкB binding, but lacks the transcriptional activation function that is found in domains $\mathrm{COOH}$-terminal to the RHD in RelA (p65), Rel (c-Rel), and RelB $(45,46)$.

Specific inhibition of NF-кB would provide a useful approach for a study of the role of this factor in gene expression in endothelial cells, and most importantly could be used as a potential therapeutic approach to prevent endothelial cell activation. At present, a number of inhibitors, (such as the antioxidant metal ion chelator pyrrolidine dithiocarbamate) are effective at inhibiting NF-кB (47), however, posttranscriptional activities of antioxidants not affecting NF- $\mathrm{B}$ activity have been reported (48). Likewise, the use of protease inhibitors not only affects NF-кB activation, but also affects DNA binding by NF-кB (49) and the phosphorylation of IкB (24-26, 37, $49,50)$. The more specific proteasome inhibitors have provided evidence for the crucial role of NF- $\mathrm{NB}$ in endothelial cell activation (51), however, some pleiotropic effects (especially on protein turnover in cells) are to be expected, making these agents less desirable for therapeutic purposes. Steroids, espe-

1. Abbreviations used in this paper: CAT, chloramphenicol acetyltransferase; RHD, Rel homology domain. 
cially glucocorticoids, also inhibit NF-кB activity in endothelial cells (52), perhaps contributing to their beneficial effects in the prevention of graft rejection.

A recent study from our laboratory has shown that adenovirus-mediated expression of $\mathrm{I} \kappa \mathrm{B} \alpha$ is able to inhibit induction of adhesion molecules in endothelial cells in vitro (53). Since I $\mathrm{B} \alpha$ only associates with RelA and Rel it may not inhibit the expression of genes mediated by RelB or (p52) 2 Bcl3 (e.g., $P$-selectin) (54). Although these experiments showed the effect of NF-кB inhibition in endothelial cells, adenovirus-mediated gene transfer may not be ideal therapeutically due to the limitations caused by the host immune response against the adenovirus vector $(55,56)$. In addition, the period of gene expression after transduction may not be sufficient, and cannot be controlled quantitatively. Thus, regulated expression of a stable transgene would be preferable. To date, stable and regulated expression of transgenes can only be achieved in transgenic animals. This expression of transgenes would be an especially feasible therapeutic approach for xenotransplantation because transgenic animals such as pigs can be used as donors of immediately vascularized organs.

We have developed and studied a specific transdominant inhibitor of NF- $\mathrm{KB}$ in the form of a COOH-terminal truncation derivative of RelA, containing only the RHD (p65RHD), and excluding the transactivation domain. The rationale was to generate an inhibitor of NF-kB that functions at the DNA level (rather than as a cytoplasmic retention activity for $\mathrm{NF}-\mathrm{kB}$ ) to maximize the spectrum of inhibited genes (irrespective of the $\mathrm{NF}-\kappa \mathrm{B}$ complex that normally activates a particular gene) because it is expected that p65RHD will inhibit any NF- $\mathrm{BB}-$ dependent gene if it binds to at least one essential NF-кB site in that gene.

We show that p65RHD is able to decrease strongly the expression of cytokine-inducible reporter constructs such as tissue factor, E-selectin, IL-8, IL-6, and I $\mathrm{B} \alpha$ in bovine aortic endothelial cells (BAEC). We have chosen these cells because of their high transfection efficiency. p65RHD-mediated inhibition is dose dependent, and occurs even at relatively low p65RHD levels. Furthermore, stable, inducible expression of p65RHD in primary endothelial cells also inhibits induction of endogenous genes like $E$-selectin and $P$-selectin which are normally induced upon cytokine or endotoxin activation. We propose that the specific and efficient inhibition of NF- $\mathrm{BB}$-dependent gene expression by p65RHD is achieved mainly by replacing transactivating NF-кB complexes with complexes containing p65RHD at the DNA target sites. The regulable expression of this NF- $\mathrm{B}$ inhibitor may provide a potent therapeutic tool to inhibit endothelial cell activation in vivo in transgenic animals to be used as donors for immediately vascularized organ xenotransplantation.

\section{Methods}

Plasmid constructs. p65RHD was generated by a PCR-based approach from the plasmid pCMV4T $\Delta$ p65 (57), which contains the full length cDNA of human RelA (pCMV4T $\Delta$ p65 was kindly provided by Dr. Warner Greene). The $5^{\prime}$ primer sequence was $5^{\prime}$-TAT TGG ATC CTG ACG AAC TGT TCC CCC TCA TC-3', and the $3^{\prime}$ primer sequence was 5'-TAC GTG TCG ACT ATT ATC CGC TGA AAG GAC TCT TCT TC-3'. The generated PCR fragment was digested with BamHI and $\mathrm{XbaI}$ to generate $5^{\prime}$ overhangs, and cloned along with an oligomer (coding for 10 amino acids of the human $c$-myc gene and having a HindIII compatible overhang on the $5^{\prime}$ and a BamHI compatible overhang on the $3^{\prime}$ end) into HindIII/XbaI cut pRC.CMV (Invitrogen Corp., San Diego, CA).

The construct is referred to as $\mathrm{pRC} . \mathrm{CMV} / \mathrm{p} 65 \mathrm{RHD}$, and codes for amino acids $2-319$ of human RelA preceded by a 13 -amino acid sequence containing 10 amino acids from the human $c-m y c$ gene (used as recognition sequence for the ATCC monoclonal antibody CRL 1729 [58]). For the generation of stably transfected BAEC, the HindIII/XbaI-cut p65RHD was cloned into EcoRI/XbaI-cut pUHD10-3 (59) by filling in the HindIII and EcoRI sites, respectively, with the Klenow fragment of Escherichia coli DNA polymerase I. The resulting plasmid is named pUHD10-3/RHD. pUHD10-3, pUHD15-1 and pUHD172-1neo were a kind gift from $\mathrm{H}$. Bujard.

Reporter constructs. The $\mathrm{I}_{\kappa} \mathrm{B} \alpha(60)$ and tissue factor (7) reporters were described previously. The E-selectin reporter construct EL$1286 /+482$ (61) represents bp -1286 to +482 of the porcine E-selectin promoter. The human IL-8 reporter was kindly provided by I. Lindley, the human IL- 6 reporter and the $2 \times \kappa \mathrm{B}$ reporter were a kind gift from R. De Martin, and the RSV-luc construct was a kind gift from A. Palmetshofer (62).

Transient transfections. Primary BAEC were grown in DME supplemented with $10 \% \mathrm{FBS}$, penicillin $\mathrm{G}(50 \mathrm{U} / \mathrm{ml})$, and streptomycin $(50 \mu \mathrm{g} / \mathrm{ml})$. Cells were seeded at $3 \times 10^{5}$ cells $/ 30 \mathrm{~mm}$ well and transfected 20-24 h later with Lipofectamine (GIBCO BRL, Gaithersburg, MD) according to the manufacturer's suggestions. The cells were exposed to $1.5 \mu \mathrm{g}$ total DNA together with $4 \mu \mathrm{l}$ of Lipofectamine in DME without FBS for $5 \mathrm{~h}$. A CMV- $\beta$-galactosidase reporter plasmid was included to allow correction for differences in transfection efficiency. After addition of FBS to a final concentration of $10 \%$, the cells were allowed to recover for $48 \mathrm{~h}$. For stimulation experiments, cells were incubated with LPS (Sigma Chemical Co., St. Louis, MO) at $200 \mathrm{ng} / \mathrm{ml}$ for $7 \mathrm{~h}$. Cell extracts were prepared by repeated freeze-thaw lysis in phosphate buffer, and assayed for luciferase (63) and $\beta$-galactosidase activity in a MicroLumat LB96P (Berthold Systems, Inc., Aliquippa, PA). The respective substrates were obtained from Sigma and Tropix Inc. (Bedford, MA). Luciferase readings were normalized to $\beta$-galactosidase or protein levels to account for differences in transfection efficiency. Each experiment was done in triplicates, and several experiments have been performed with plasmids from different DNA preparations to assess the influence of DNA quality.

Stable transfections. Transfections were done as described above using third passage BAEC. The molar ratio of plasmid pUHD1721neo and pUHD10-3/RHD used in the transfection was 1:4. $24 \mathrm{~h}$ after transfection, cells from three $30-\mathrm{mm}$ wells were trypsinized, pooled, and seeded into 48 well plates, and stable transfectants were selected using $600 \mu \mathrm{g} / \mathrm{ml}$ Geneticin (GIBCO BRL) for $14 \mathrm{~d}$. Only wells with one colony were used for further experiments. To determine expressing clones, cells were incubated with medium containing $2 \mu \mathrm{g} / \mathrm{ml}$ doxycycline (Sigma Chemical Co., St. Louis, MO) for $24 \mathrm{~h}$ and stained for p65RHD as described below.

Chloramphenicol acetyltransferase (CAT) reporter assays. CAT assays were performed essentially as recommended (Promega Technical Bulletin TB084) by the supplier of the CAT assay kit (Promega, Madison, WI). Briefly, transfected cells were lysed by repeated freezethaw cycles (64). The extracts were incubated with $\left[{ }^{14} \mathrm{C}\right]$ chloramphenicol and $n$-butyryl-coenzyme A. The reaction products were then extracted several times with xylene (65). The combined organic phases were mixed with scintillation liquid and counted in a scintillation counter (1900 TR, Packard Instruments, Inc., Downers Grove, IL).

Northern and Western blot analysis. Stably transfected BAEC were incubated with $2 \mu \mathrm{g} / \mathrm{ml}$ doxycycline for $24 \mathrm{~h}$ before addition of LPS $(200 \mathrm{ng} / \mathrm{ml})$ for additional $2 \mathrm{~h}$. Total RNA and protein were extracted using TRIzol (GIBCO BRL) according to manufacturer's instructions. $20 \mu \mathrm{g}$ of RNA were separated on an agarose gel containing formaldehyde, transferred to a Hybond-N nylon membrane (Amersham Corp., Arlington Heights, IL) and analyzed by hybridization to radiolabeled cDNA probes of porcine IкB $\alpha$ (gift from R. de Martin 


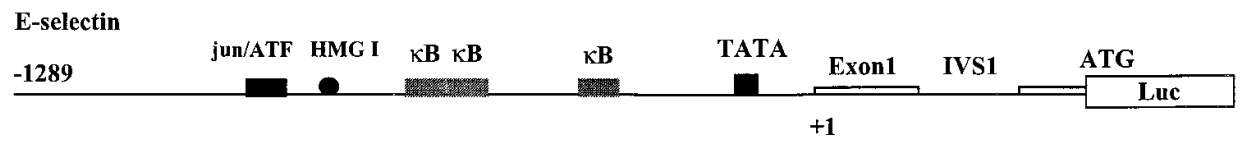

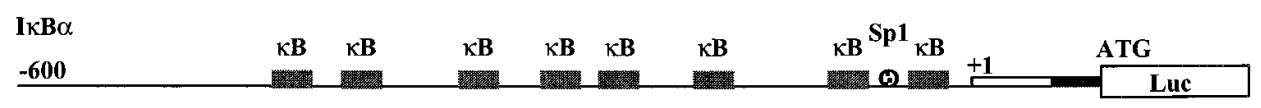

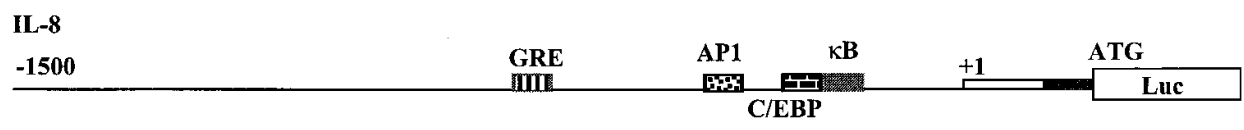

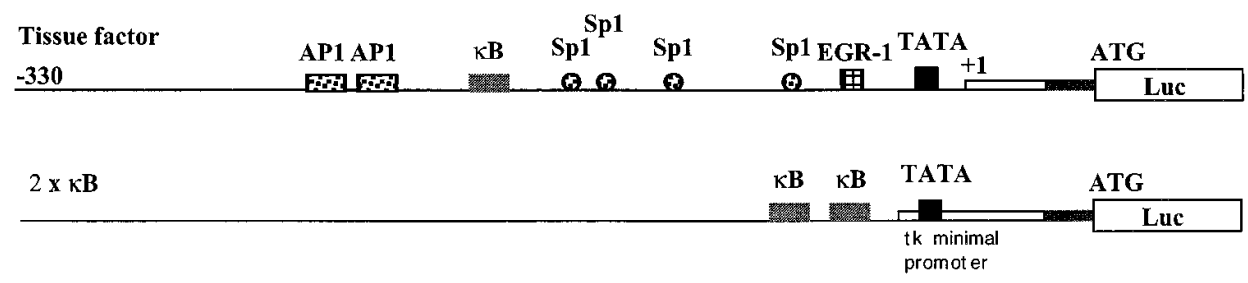

B



C

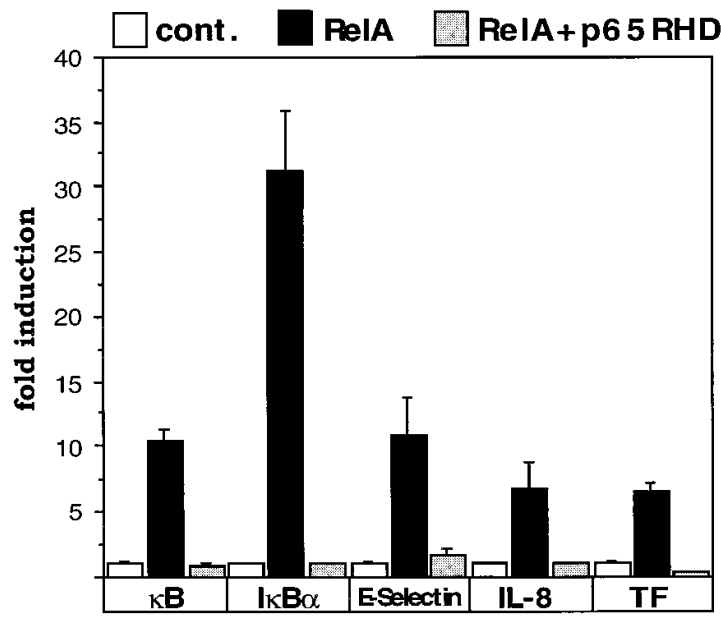

Figure 1. Inhibition of RelA-mediated transcription by p65RHD. $(A)$ Graphic representation (not to scale) of the luciferase reporter constructs used in this study. Binding sites for transcription factors are indicated. +1 indicates the transcription start site. $(B)$ BAEC were transiently transfected with constant amounts of pCMV4T $\Delta$ p65 (RelA) and increasing amounts of pRC.CMV/p65RHD (p65RHD) along with $700 \mathrm{ng}$ of an $\mathrm{I} \kappa \mathrm{B} \alpha$-luciferase reporter construct. (C) BAEC were transiently transfected with pCMV4T $\Delta$ p65 (RelA) alone or together with equal amounts of pRC.CMV/p65RHD (p65RHD, $300 \mathrm{ng}$ ) along with $700 \mathrm{ng}$ of different luciferase reporter constructs as indicated. Basal luciferase activity was normalized to $\beta$-galactosidase activity for each reporter (tissue factor reporter activity was normalized to protein concentration) and was set to 1 and fold induction was calculated accordingly. Bars represent averages from triplicate transfections \pm standard deviation. 
[60]), bovine E-selectin and bovine P-selectin (both obtained from J. Bischoff, Children's Hospital, Boston). All membranes were probed for glyceraldehyde-3-phosphate dehydrogenase (GAPDH) mRNA to correct for unequal loading (66), and all quantitated IкB $\alpha$, E-selectin, and P-selectin transcript levels were adjusted accordingly.

For Western blot analysis equal amounts of protein were boiled in SDS sample buffer, and electrophoresis under denaturing conditions was carried out on a $10 \%$ polyacrylamide gel. After transfer to a PVDF (polyvinyldifluoridine) membrane (Immobilon P; Millipore Corp., Bedford, MA) by electroblotting and probing with a polyclonal antibody directed against the $\mathrm{NH}_{2}$-terminal region of human RelA (Santa Cruz Biotechnology Inc., Santa Cruz, CA) bands were visualized using horseradish peroxidase conjugated donkey anti-rabbit IgG (Pierce, Rockford, IL) and the Enhanced ChemiLuminescence assay (Amersham Corp.) according to manufacturer's instructions.

Nuclear extracts and electrophoretic mobility shift assay (EMSA). Stable transfected BAEC were either left untreated or were incubated with doxycycline $(2 \mu \mathrm{g} / \mathrm{ml})$ for $24 \mathrm{~h}$. Cells were stimulated with LPS $(200 \mathrm{ng} / \mathrm{ml})$, and nuclear proteins were extracted as described (67). All the buffers were supplemented with $0.1 \mathrm{mM}$ TPCK, $0.1 \mathrm{mM}$ TLCK (Sigma) $1 \mu \mathrm{g} / \mathrm{ml}$ Aprotinin, and $1 \mu \mathrm{g} / \mathrm{ml}$ Leupeptin (Boehringer Mannheim Corp., Indianapolis, IN). The NF-kB-specific double-stranded oligonucleotide (5'-AATTTCAGAGGGGGATTTCCCAGAGG-3') contains an NF-кB binding site from the human $\kappa$ light-chain promoter (68) and was labeled using a Klenow fragment of E. coli DNA polymerase in the presence of dNTPs and $\left[\alpha{ }^{32} \mathrm{P}\right] \mathrm{dATP} .10 \mu \mathrm{g}$ of nuclear extract were incubated with 100,000 $\mathrm{cpm}$ of radiolabeled $\mathrm{NF}-\mathrm{\kappa B}$ oligonucleotide at room temperature for $30 \mathrm{~min}$, and the resulting complexes were separated on a $5 \%$ polyacrylamide gel in Tris/Glycine/EDTA buffer at $\mathrm{pH} 8.5$ as described previously (47). For supershift experiments, nuclear extracts were incubated with NF- $\mathrm{KB}$ oligonucleotide as described above followed by $1 \mathrm{~h}$ incubation with NF-кB1, COOH-terminal or $\mathrm{NH}_{2}$-terminal RelA polyclonal antibodies (all Santa Cruz Biotechnology) before electrophoretic separation.

\section{Results}

In this study we tested the hypothesis that a transdominant negative mutant of RelA can effectively interfere with NF- $\mathrm{KB}-$ dependent transcriptional induction of a number of genes that play a major role in endothelial cell activation; such a mutant could be used to reveal NF-кB dependence of gene upregulation, and may be useful as a therapeutic tool to prevent endothelial cell activation. We have constructed a derivative of the human RelA protein, to which we refer as p65RHD. This protein lacks the $\mathrm{COOH}$-terminal transactivation domain, and contains a 10 amino acid epitope of the human c-Myc protein at the $\mathrm{NH}_{2}$ terminus. p65RHD contains amino acids 2 to 320 lacking the COOH-terminal 231 amino acids of the wild-type RelA protein. Thus, p65RHD essentially comprises the "Rel homology domain" that allows specific subunit interactions as well as DNA binding but lacks the transactivation domain.

Expression of p65RHD inhibits RelA-mediated transcription. The efficacy of p65RHD as a transdominant inhibitor of $\mathrm{NF}-\kappa \mathrm{B}$ was analyzed in two ways. First, to address specifically the question whether p65RHD effectively interferes with RelA-induced transcription, we used a RelA expression plasmid (controlled by the same cytomegalovirus [CMV] enhancer as p65RHD) to induce various reporter plasmids (Fig. $1 A$ ). Fig. $1 B$ shows the results of a representative titration experiment. We have chosen the Iк $\mathrm{B} \alpha$ reporter for this titration experiment because its induction by RelA is much higher than any of the other reporters we have tested (Fig. $1 C$ ). Expres- sion of equal amounts of p65RHD and RelA (as confirmed by Western blot analysis; data not shown) resulted in almost total inhibition of reporter activation. Induction of reporter activity by co-expression of p50 and RelA was similarly inhibited by p65RHD (data not shown). At a 1:1 ratio of RelA:p65RHD, potent inhibition of the tissue factor IL-8, E-selectin, and a solely NF-кB dependent reporter $(2 \times \kappa \mathrm{B})$ was also observed (Fig. $1 C$ ).

Expression of p65RHD inhibits transcription mediated by endogenous $N F-\kappa B$ activated by LPS. To study transcriptional activation by endogenous NF- $\mathrm{B}$, endothelial cells were transiently transfected with p65RHD plus reporter plasmids for IL-8, E-selectin, IкB $\alpha$, or tissue factor. Induction of transcription with LPS was strongly inhibited by p65RHD for all reporters (Fig. 2). Inhibition of transcriptional activation was dose-dependent and reached maximal levels at almost equal amounts of reporter and p65RHD expression plasmid (600 ng p65RHD plasmid, $700 \mathrm{ng}$ reporter plasmid). Significant inhibition of IL-8 reporter activity was observed already at very low levels of p65RHD expression: $20 \mathrm{ng}$ p65RHD together with $700 \mathrm{ng}$ IL-8 reporter plasmid resulted in approximately $50 \%$ inhibition of IL-8 reporter activity (Fig. $2 C$ ). The data presented in Figs. 1 and 2 clearly show that the transcriptional induction of these genes is dependent on NF-кB. Relative luciferase values in Fig. 2 were adjusted to fit the same scale.

Tetracycline regulated, transient expression of p65RHD. To test whether sufficient, regulable expression of p65RHD can be achieved to block gene induction, we have expressed p65RHD using the tetracycline-regulated system first described by Gossen and Bujard (59). In this system, p65RHD
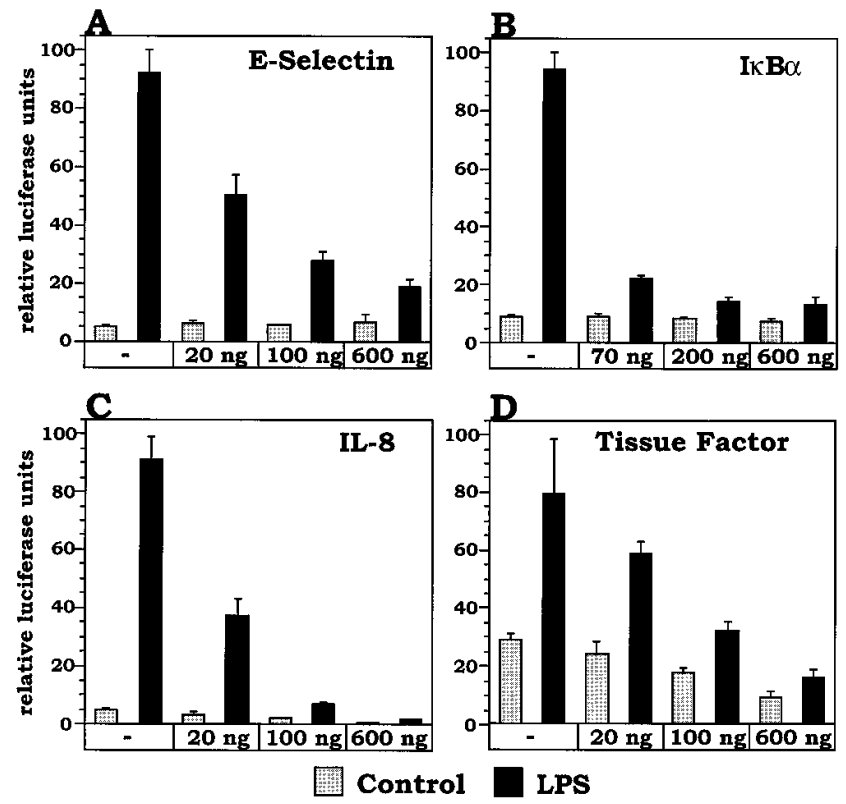

D

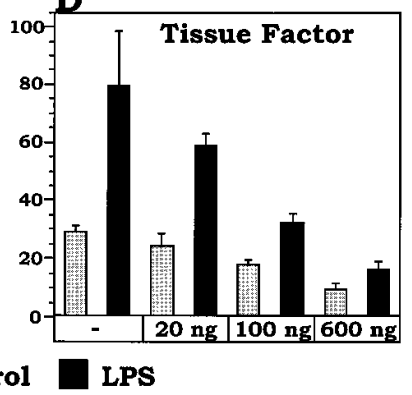

Figure 2. Inhibition of LPS-induced transcription by p65RHD. BAEC were transiently transfected with $700 \mathrm{ng}$ of E-selectin $(A)$, $\mathrm{I} \kappa \mathrm{B} \alpha(B), \mathrm{IL}-8(C)$, and tissue factor $(D)$ reporter constructs along with increasing amounts of pRC.CMV/p65RHD (p65RHD) as indicated. $48 \mathrm{~h}$ after transfection, cells were stimulated with $200 \mathrm{ng} / \mathrm{ml}$ LPS for $7 \mathrm{~h}$. Bars represent averages from triplicate transfections \pm standard deviation. Luciferase activity was normalized according to $\beta$-galactosidase activity except for $(D)$, where protein concentration was used for normalization. 
I $\kappa \mathbf{B} \alpha$ reporter

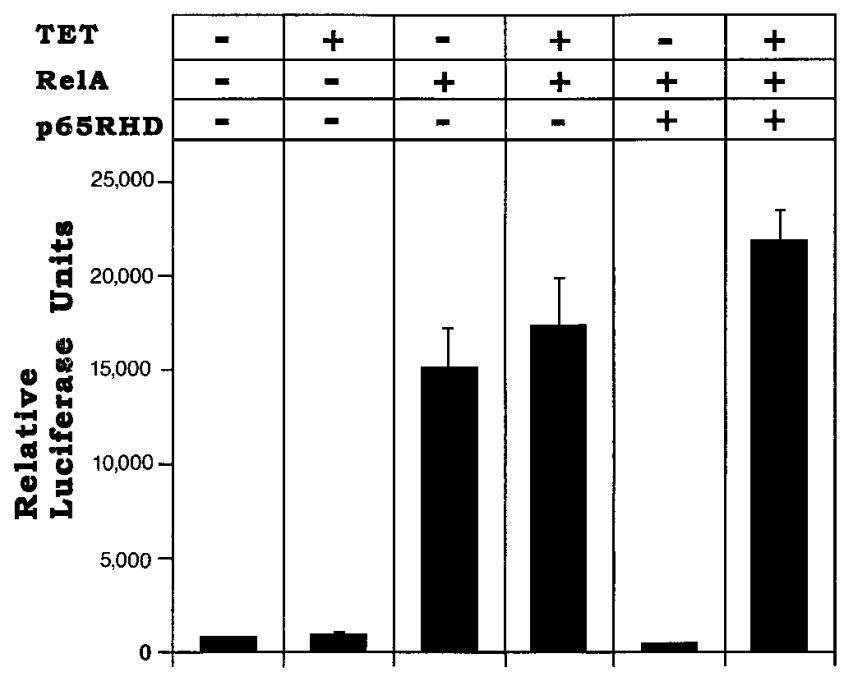

Figure 3. Tetracycline-mediated expression of p65RHD inhibits RelA-induced transcription of the IкB $\alpha$ promoter. BAEC were transiently transfected with $300 \mathrm{ng}$ of the tetracycline-repressible transactivator expression plasmid pUHD15-1 (tet-off), 300 ng of pUHD10-3/ RHD (p65RHD) and $300 \mathrm{ng}$ pCMV4T $\Delta$ p65 (RelA) together with 400 ng of the IкB $\alpha$ reporter. In transfections where one or more plasmids were left out, the total amount of DNA was kept constant by adding pRC.CMV. Where indicated, tetracycline (TET) was added immediately after the transfection to a final concentration of $20 \mu \mathrm{g} / \mathrm{ml}$. Cell extracts were prepared $48 \mathrm{~h}$ after transfection. Bars represent averages from triplicate transfections \pm standard deviation.

expression is controlled by a tetracycline-sensitive transcriptional activator (tTA, tet-off). Its expression is induced in the absence of tetracycline and repressed by low levels of tetracycline, which inhibits the DNA binding of the tetracycline repressor-VP16 fusion protein (tet-off). As shown in Fig. 3, RelA-mediated induction of the I $\mathrm{B} \alpha$ reporter was completely inhibited by p65RHD (expressed in the absence of tetracycline), whereas no inhibition was observed in the presence of tetracycline (which prevents p65RHD expression by tTA [tetoff]). To allow for the inclusion of the tTA expression plasmid, a lower concentration of $\mathrm{I} \kappa \mathrm{B} \alpha$ reporter plasmid as well as a lower concentration of $\beta$-galactosidase expression plasmid have been used in these experiments. Since all luciferase values are normalized to $\beta$-galactosidase values, this results in lower relative light units in this experiment as compared to the experiment in Fig. $1 B$.

Stimulus independence and specificity of inhibition. In addition to LPS we have used TNF $\alpha$ to induce the E-selectin reporter. We find that there is less potent induction by TNF $\alpha$ (100 U), although inhibition by p65RHD is unchanged. To demonstrate specificity of p65RHD, we have transiently transfected BAEC with a luciferase reporter plasmid under the control of the Rous sarcoma virus (RSV) enhancer/promoter. Cotransfection with $600 \mathrm{ng}$ of p65RHD expression plasmid does not significantly change the constitutive expression from this construct (Fig. $4 B$ ). We also employed a HIV long terminal repeat (HIV-LTR) driven chloramphenicol-acetyl-transferase (CAT) reporter (69) that can be induced both by a NF- $\kappa \mathrm{B}$-dependent mechanism (expression of the Human T Lymphotropic Virus-1 [HTLV-1]-Tax protein or p65/RelA) and by a NF-кB-independent mechanism (expression of HIVTat protein). HTLV1 Tax-mediated, NF-кB-dependent, as well as p65/RelA-mediated activation of this reporter is inhibited by coexpression of p65RHD. In contrast, the NF $\kappa \mathrm{B}$-independent transcriptional activation of the same reporter by expression of the HIV-Tat protein is not inhibited by p65RHD (Fig. $4 C$ ). Taken together these data clearly establish the specificity of p65RHD-mediated inhibition directed at NF- $\mathrm{B}$ dependent transcription.

Stable transfection of BAEC. To analyze the effect of p65RHD on endogenous gene expression, we have generated bovine aortic endothelial cells expressing p65RHD in a doxycyclineinducible manner. We have stably integrated into these cells two plasmids: one (p172-1neo) encodes the tetracycline inducible (tet-on) transcriptional activator rtTA (70) (also referred to as the reverse tetracycline-regulated transcription activator), and the other contains p65RHD expressed under the control of rtTA (71). The rtTA is a mutant derivative of tTA, and exhibits opposite DNA-binding activity in response to tetracycline in that its DNA binding is induced, rather than inhibited, by tetracycline. Stable integration of this expression system in cells provides the opportunity to study the effects of NF- $\mathrm{B}$ inhibition on endogenous gene expression in a regulated manner. Doxycycline (a more potent derivative of tetracycline)inducible expression of p65RHD over time was analyzed by Western blotting, using a RelA- $\mathrm{NH}_{2}$ terminus-specific antibody (Fig. 5). Maximal expression levels were reached after $16 \mathrm{~h}$ and were maintained for at least $72 \mathrm{~h}$. Immunocytochemical analysis, using a c-myc epitope-specific monoclonal antibody, shows predominantly nuclear localization of p65RHD in cells treated with doxycycline (data not shown). Although ectopically expressed p65RHD is capable of interacting with endogenous IкB (data not shown), it was also found predominantly in nuclear extracts of transiently transfected resting and activated endothelial cells.

DNA binding of $p 65 R H D$. The hypothesis that p65RHD functions as a competitive inhibitor of NF- $\mathrm{B}$-dependent transcription at the level of DNA binding requires that p65RHD is capable of binding to NF- $\mathrm{B}$ recognition sites. Nuclear extracts prepared from stably transfected BAEC induced with doxycycline show a specific DNA-binding activity that recognizes NF-кB binding sites (Fig. 6, lane 3). When these cells were induced with LPS in the presence of doxycycline, there was no interference of p65RHD expression with the activation of endogenous NF-кB (Fig. 6, lane 5). In addition, there was a noticeable increase in the p65RHD complex, suggesting that part of the p65RHD protein was sequestered (presumably by IкB) in the cytoplasm of quiescent cells. The mobility of the p65RHD complex, which migrates slightly faster than NF- $\mathrm{B} 1$ homodimers, suggests binding of either p65RHD homodimers or p65RHD/NF-kB1 heterodimers. To further analyze the composition of the p65RHD-containing complex, we performed supershift experiments using NF-кB1- and RelA-specific antibodies. Our results demonstrate that neither the NFкB1 (Fig. 6, lanes 7-10) nor the $\mathrm{COOH}$ terminus-specific RelA antibody (Fig. 6, lanes 15-18) recognized the p65RHDcontaining complex. However, the $\mathrm{NH}_{2}$ terminus-specific RelA antibody resulted in a supershift of the p65RHD-containing complex (Fig. 6, lanes 11-14). The endogenous NF-кB complexes were supershifted as expected (Fig. 6, lanes 9, 13, and 17). Taking into account the mobility of the p65RHD complex and the results of the supershift experiments, we con- 


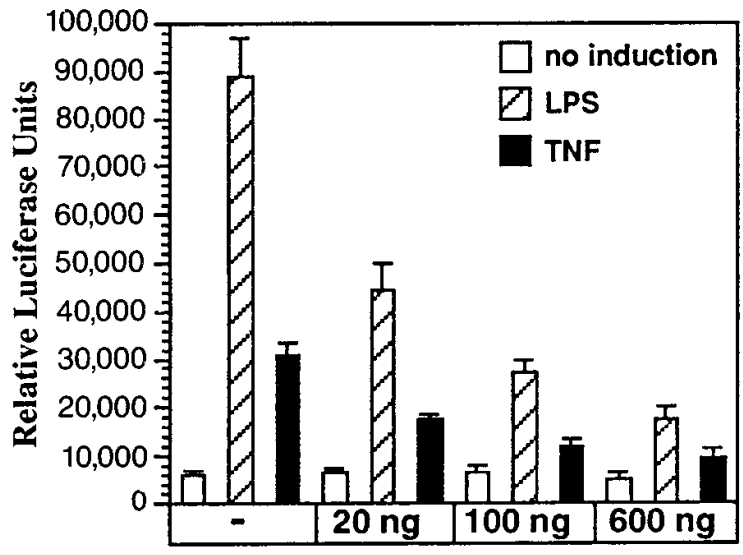

C

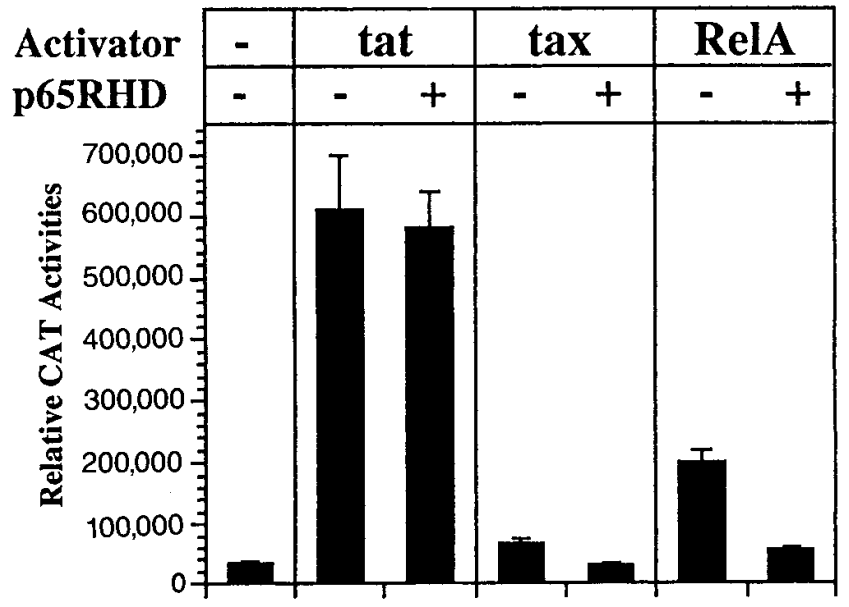

0

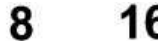

24

48

72

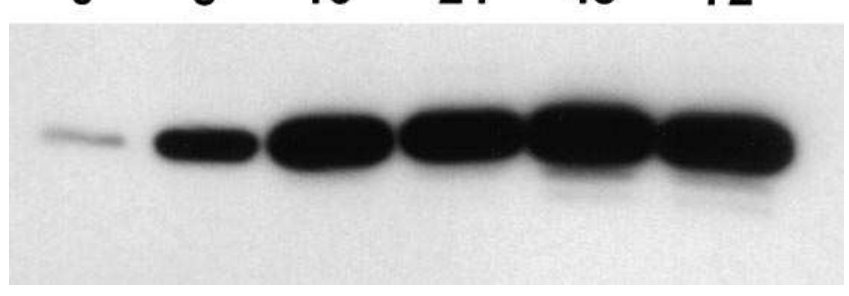

Figure 5. Doxycycline-induced expression of p65RHD in stably transfected BAEC. BAEC were transfected with pUHD172-1neo (coding for the tetracycline inducible transactivator; tet-on) and pUHD10-3/RHD (Myc-tagged p65RHD cDNA under the control of 7 copies of the Tet-operon; TetO) and selected on G418 as described in Methods. Expression of p65RHD was induced with $2 \mu \mathrm{g} / \mathrm{ml}$ doxycycline. Whole cell extracts were prepared at time $0,8,16,24,48$, and $72 \mathrm{~h}$, separated by SDS-PAGE, blotted on a PVDF membrane and probed with a polyclonal antibody directed against a $\mathrm{NH}_{2}$-terminal epitope of RelA. Bands were revealed using a horseradish peroxidase-conjugated anti-rabbit-IgG antibody and an enhanced chemiluminescent system.

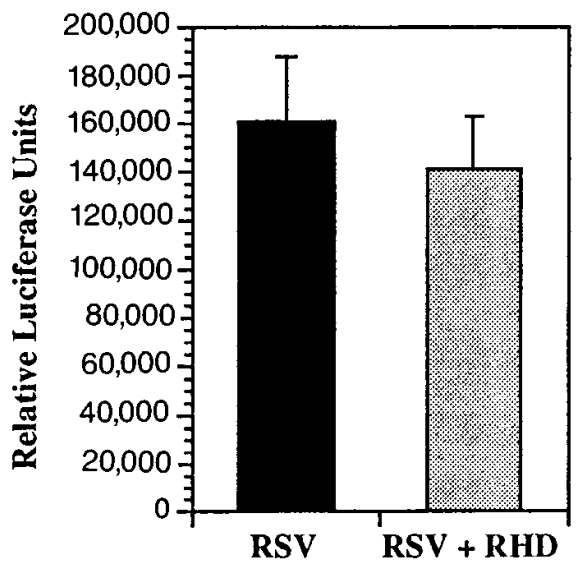

Figure 4. Stimulus independence and specificity of p65RHD activity. $(A) \mathrm{BAEC}$ were transfected with an E-selectin reporter and the indicated amount of p65RHD expression plasmid. Cells were either left untreated (open bars) or stimulated with either $200 \mathrm{ng}$ LPS (hatched bars) or $100 \mathrm{U}$ human recombinant TNF $\alpha$ (solid bars). (B) BAEC were transfected with the RSV-luciferase reporter in the absence (black bar) or presence (gray bar) of $600 \mathrm{ng}$ of p65RHD expression plasmid. $(C)$ BAEC were transfected with the HIV-LTR-CAT plasmid (700 ng). Transcription from this reporter was activated by cotransfection of HIV-Tat (tat), HTLV1-Tax (tax) or p65/RelA (RelA) expression plasmids $(300 \mathrm{ng})$ in the absence $(-)$ or presence $(+)$ of 300 ng p65RHD expression plasmid.

clude that the majority of p65RHD within the cells binds to DNA as homodimers. This cannot be entirely due to the excess of p65RHD within the cells because LPS-induced cells that were not treated with doxycycline, and are therefore due to "leakage" of the expression system, also showed a weak p65RHD-containing bandshift (Fig. 6, lane 4) of the same quality as the stronger, doxycycline-induced complex.

Tetracycline-regulated, stable expression of p65RHD inhibits induction of endogenous genes in endothelial cells. To test doxycycline-regulable inhibition of endogenous, LPS-inducible gene expression in these cells, the following experiment was carried out. Stably transfected BAEC were induced with LPS for $2 \mathrm{~h}$ in the presence or absence of doxycycline. RNA and protein was isolated and analyzed by Northern (Fig. $7 \mathrm{~A}$ ) and Western blotting (Fig. $7 B$ ), respectively. Lanes 1 and 2 in Fig. $7 A$ show inducible expression of $E$-selectin, $P$-selectin and $I \kappa B \alpha$, an example of a strictly $\mathrm{NF}-\kappa \mathrm{B}$ regulated gene (60, 72 ) in the absence of p65RHD expression. However, when p65RHD expression was induced by tetracycline (Fig. $7 \mathrm{~A}$, lanes 3 and 4), the LPS-mediated up-regulation of these genes 


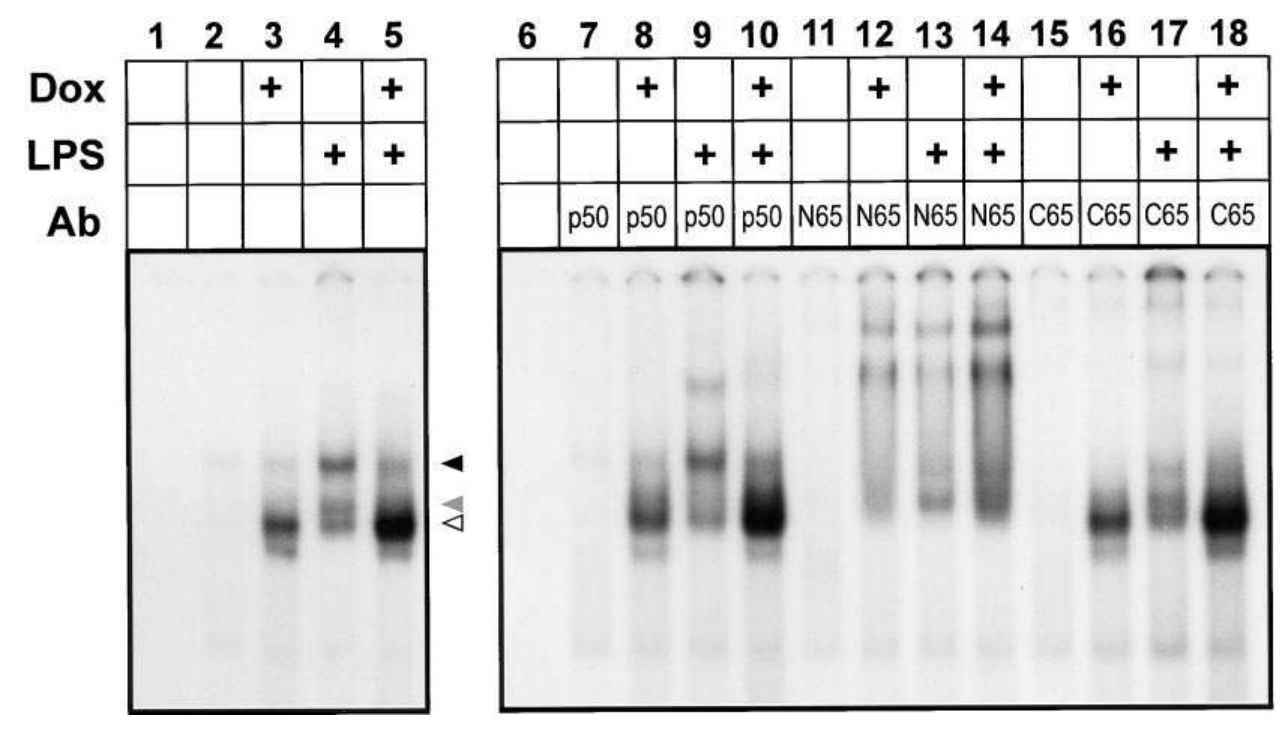

Figure 6. Electrophoretic mobility shift assay of nuclear extracts from BAEC stably transfected with p65RHD. Nuclear extracts were prepared from cells left untreated (lane 2) and treated with $200 \mathrm{ng} / \mathrm{ml}$ LPS for $2 \mathrm{~h}$ (lane 4 ). Cells were treated with doxycycline for $24 \mathrm{~h}$ and stimulated with LPS as described above (lane 5) or left unstimulated (lane 3). Extracts were incubated with ${ }^{32} \mathrm{P}$-labeled IgкB oligonucleotide and electrophoretically separated as described in Materials. NF-кB1-RelA heterodimers (solid arrow) are indicated as well as the position of p65RHD (gray arrow). For supershift experiments, antibodies specific for NF-кB1 ( $p 50$, lanes 7-10), N-terminus of RelA (N65, lanes 11-14) and C-terminus of RelA (C65, lanes 15-18) were used. Lanes 1 and 6 show the free probe.
A

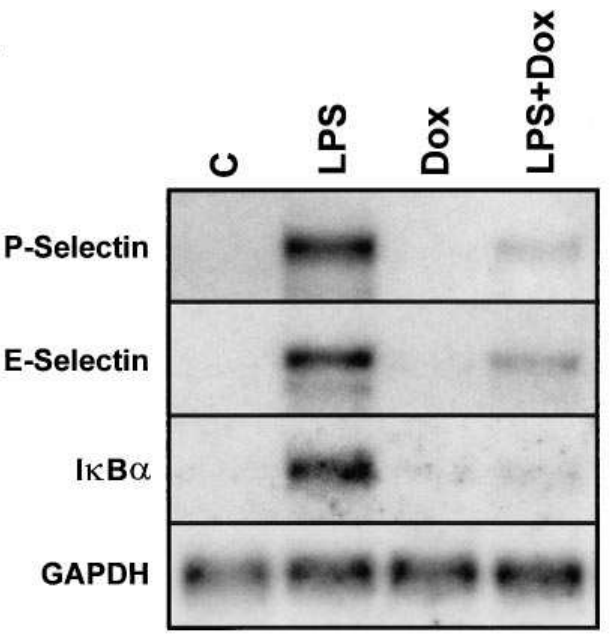

B

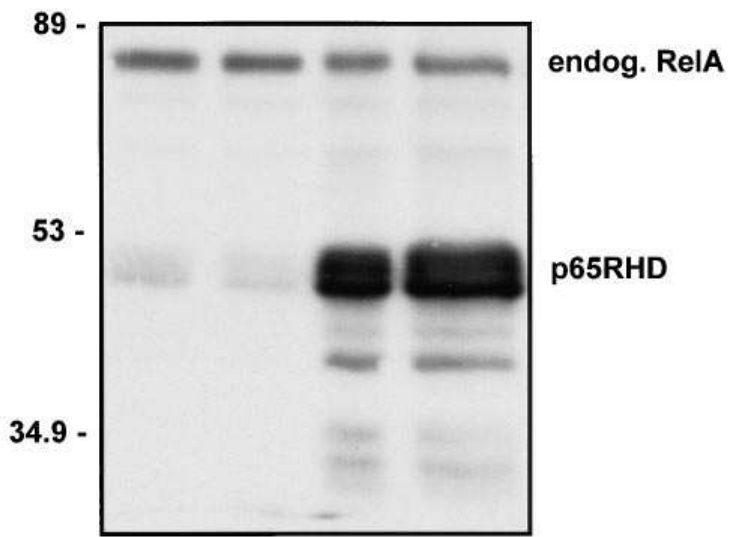

Figure 7. Expression of p65RHD inhibits LPS-induced upregulation of endogenous NF- $\mathrm{BB}$ dependent genes. $(A)$ Stably transfected BAEC were left untreated (lanes 1 and 2) or p65RHD expression was induced with $2 \mu \mathrm{g} / \mathrm{ml}$ doxycycline for $24 \mathrm{~h}$ (lanes 3 and 4 ). After induction with LPS for $2 \mathrm{~h}$ (lanes 2 and 4), total RNA and protein was was inhibited. Quantification by densitometer scanning reveals that mRNA accumulation of P-selectin was inhibited by approximately $88 \%$, E-selectin by approximately $67 \%$ and IкB $\alpha$ by approximately $90 \%$ when compared to mRNA levels of cells not treated with doxycycline.

\section{Discussion}

In this study, we investigated the feasibility of inhibiting gene up-regulation in endothelial cell activation by engineering a specific, transdominant negative derivative of the Rel/NF- $\mathrm{B}$ protein RelA. The rationale for devising a RelA-specific inhibitor is based on the finding that, of all Rel/NF- $\mathrm{B}$ proteins, RelA is ubiquitously present in active NF- $\mathrm{B}$ complexes, and contains the strongest transcription activation domain. RelA is therefore expected to contribute the most to NF- $\mathrm{B}$-dependent transcription. Furthermore, p65RHD is expected to function as a competitor for DNA binding of all NF- $\mathrm{kB} / \mathrm{Rel}$ proteins, whether they are inhibited by ІкB-like proteins or not. The use of p65RHD has allowed us to inhibit NF-кB in endothelial cells specifically and effectively by interfering with ectopically-expressed RelA, and with endogenous NF-кB activity (Figs. $1 B, 1 C, 2$, and 7). Furthermore, its effect unequivocally demonstrates the critical role of NF- $\mathrm{B}$ in inducible gene expression in endothelial cells. We have used LPS for most of this study because it is the most potent agonist of $\mathrm{NF} \kappa \mathrm{B}$ activation and of transcriptional induction of gene expression in BAEC. For reference we have used TNF $\alpha$ in select cases

prepared as described in Materials and Methods. The blot was probed with radiolabeled probes for bovine P- and E-selectin, porcine $\mathrm{I} \kappa \mathrm{B} \alpha$, and human GAPDH. $(B)$ Protein extracts prepared from the same cells were separated by SDS-PAGE and probed with polyclonal antibody directed against a N-terminal epitope of RelA. Bands were revealed using a horseradish peroxidase (conjugated anti-rabbit-IgG antibody and a enhanced chemiluminescent system). 
(Fig. 4). IL-1 $\beta$ was not used because none of the available preparations of this cytokine cross-react with bovine cells.

From Figs. 2 and 7 it is clear that inhibition of E-selectin was never complete, even at high p65RHD levels. There are at least two possible explanations for this highly-reproducible phenomenon ( $>10$ independent experiments). The remaining activity of the E-selectin promoter at maximal levels of p65RHD may be due to NF-кB independent transcription. Alternatively, p65RHD may not be capable of competing $100 \%$

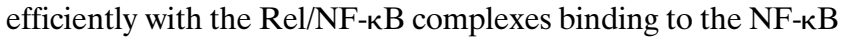
elements in the E-selectin regulatory region. In this case, the remaining promoter activity could be due to residual NF-кB activity associated with the E-selectin promoter. In addition, unlike other reporters, the considerable basal activity of the E-selectin reporter was not inhibited by p65RHD. This basal reporter activity might be $\mathrm{NF}-\kappa \mathrm{B}$ independent, or may be mediated by a form of Rel/NF-кB complex that is not amenable to 65RHD inhibition.

In contrast to E-selectin, IL-8 was most effectively inhibited by p65RHD (Fig. 2 C): transfection of $20 \mathrm{ng}$ p65RHD expression plasmid with $700 \mathrm{ng}$ IL-8 reporter plasmid resulted in $50 \%$ inhibition, and $100 \%$ inhibition was reached at $100 \mathrm{ng}$ of p65RHD plasmid. This result may reflect the special requirement of the $I L-8$ promoter for RelA as described by Kunsch et al. (13). These authors have shown that only RelA, Rel, and p52 are able to bind to the NF- $\mathrm{BB}$ binding site in the $I L-8$ promoter in vitro, and that it is mainly RelA that contributes to $I L-8$ promoter activity. Furthermore, they show that coexpression of RelA and p50 did not induce $I L-8$ promoter activity, whereas expression of RelA alone did so efficiently. Taken together, this evidence may explain the increased sensitivity of $I L-8$ induction to interference with RelA activity.

With some reporters, non-induced basal transcriptional activity was reproducibly reduced by p65RHD expression (Figs. 1 and 2). We hypothesize that the basal transcriptional activity of these reporters is due to low-level NF-кB activity in "uninduced" cells that may be a result of the transfection procedure.

Important for many uses of a genetic inhibitor of $\mathrm{NF}-\mathrm{KB}$ (such as p65RHD) is the ability to express the inhibitor in a regulated manner. Since homozygous null mutants of RelA are lethal in utero (73), and we expect p65RHD expression to mimic a RelA null mutation, temporal regulation of p65RHD expression is imperative. Likewise, for therapeutic use, one may not desire, for instance, to inhibit endothelial cell activation constantly and for prolonged periods of time. A transgenic animal expressing p65RHD in a regulated fashion may effectively represent a conditional RelA null mutant. The potential benefits of a regulable expression system are numerous: not only could the role of NF- $\mathrm{NB}$ be studied in many disease models in vivo, but therapeutic applications, especially in xenotransplantation where donor animals are amenable to genetic manipulation, are also conceivable. We have therefore developed and tested an inducible expression system first described by Gossen and Bujard (59) to demonstrate inducible expression of the NF-кB inhibitor in endothelial cells.

Using the tetracycline-regulated expression system in primary endothelial cells, we have found that overexpressed p65RHD is primarily localized in the nucleus (Fig. 5). A likely reason for this finding is that the extent of p65RHD overexpression saturates the cytoplasmic retention system for Rel proteins, and that the levels remaining in the cytoplasm cannot easily be detected. In accordance with such a suggestion is our finding that ectopic expression of wild-type RelA led to significant induction of several reporter constructs tested (Fig. 1), indicating that sufficient RelA entered the nucleus without cell activation by exogenous stimuli such as TNF $\alpha$ or LPS. Moreover, LPS treatment in such an experiment did not further increase reporter activity induced by RelA (data not shown).

Regulated overexpression of p65RHD decreases the LPSinduced induction of E-selectin, P-selectin, and $I \kappa B \alpha$. NF-кBdependent induction of $\mathrm{P}$-selectin reporters has been described. However, the authors show that NF-kB2 (p52) homodimers in cooperation with Bcl-3 are the only Rel proteins able to induce transcription of a P-selectin reporter (54). The efficient inhibition of endogenous $P$-selectin expression by p65RHD is therefore somewhat surprising. It is, however, likely that p65RHD, which exhibits stronger DNA binding than RelA, binds to the $P$-selectin $\mathrm{\kappa B}$ site to exert its inhibitory activity. The inhibition of $P$-selectin induction also demonstrates that p65RHD has the potential to inhibit genes that are

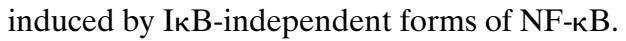

In conclusion, our data suggest that specific inhibition of $\mathrm{NF}-\kappa \mathrm{B}$ by a transdominant negative competitor markedly inhibits the induction of genes considered to be markers of endothelial cell activation. Given the specificity of p65RHD, our results also demonstrate the critical role of NF- $\mathrm{BB}$ in endothelial cell activation, pointing out that NF- $\mathrm{KB}$ activity is essential for all the genes tested. Furthermore, we show that p65RHD inhibits induction of genes like $P$-selectin, which are not likely to be inhibited by $\mathrm{I} \kappa \mathrm{B} \alpha$. Finally, our results suggest that regulated expression of p65RHD in transgenic animals may also be able to inhibit the up-regulation of proinflammatory genes in endothelial cells, and therefore prevent the chemotaxis, adhesion, and infiltration of leukocytes into the endothelium at sites of chronic and acute inflammation and in transplanted organs.

\section{Acknowledgments}

We thank Dr. Hermann Bujard for stimulating discussions, Dr. Erhard Hofer for providing the tissue factor reporter, and Dr. Warner Greene for providing plasmid pCMV4T $\Delta$ p65. We also thank Mrs. Eva Csizmadia for culturing endothelial cells.

Computer and Systems Support was supplied in part by the Research North Computing Center and its research-oriented support projects at Beth Israel Deaconess Medical Center and Harvard Medical School, Boston, MA, the Francis A. Countway Library of Medicine at Harvard Medical School, and The National Center for Biotechnology Information at the National Library of Medicine, NIH. This work was supported by a grant from Sandoz Pharma Inc., Basel, Switzerland. J. Anrather was supported by a fellowship from the Max Kade Foundation.

\section{References}

1. Weller, A., S. Isenmann, and D. Vestweber. 1992. Cloning of the mouse endothelial selectins. Expression of both E- and P-selectin is inducible by tumor necrosis factor $\alpha$. J. Biol. Chem. 267:15176-15183.

2. Wertheimer, S.J., C.L. Myers, R.W. Wallace, and T.P. Parks. 1992. Intercellular adhesion molecule-1 gene expression in human endothelial cells. Differential regulation by tumor necrosis factor- $\alpha$ and phorbol myristate acetate. $J$. Biol. Chem. 267:12030-12035.

3. Swerlick, R.A., K.H. Lee, L.J. Li, N.T. Sepp, S.W. Caughman, and T.J. Lawley. 1992. Regulation of vascular cell adhesion molecule 1 on human dermal microvascular endothelial cells. J. Immunol. 149:698-705.

4. Howells, G.L., D. Chantry, and M. Feldmann. 1988. Interleukin 1 (IL-1) and tumor necrosis factor synergise in the induction of IL-1 synthesis by human vascular endothelial cells. Immunol. Lett. 19:169-173. 
5. Chen, C.C., and A.M. Manning. 1996. TGF $\beta 1$, Il-10 and Il-4 differentially modulate the cytokine-induced expression of Il- 6 and Il-8 in human endothelial cells. Cytokine. 8:58-65.

6. Rollins, B.J., T. Yoshimura, E.J. Leonard, and J.S. Pober. 1990. Cytokine-activated human endothelial cells synthesize and secrete a monocyte chemoattractant, MCP-1/JE. Am. J. Pathol. 136:1229-1233.

7. Moll, T., M. Czyz, H. Holzmüller, R. Hofer-Warbinek, E. Wagner, H. Winkler, F.H. Bach, and E. Hofer. 1995. Regulation of the tissue factor promoter in endothelial cells: binding of NF-кB-, AP-1-, and Sp1-like transcription factors. J. Biol. Chem. 270:3849-3857.

8. Bach, F.H., S.C. Robson, C. Ferran, H. Winkler, M.T. Millan, K.M. Stuhlmeier, B. Vanhove, M.L. Blakely, W.J. van der Werf, E. Hofer, R. de Martin, and W.W. Hancock. 1994. Endothelial cell activation and thromboregulation during xenograft rejection. Immunol. Rev. 141:5-30.

9. Hiscott, J., J. Marois, J. Garoufalis, M. Daddario, A. Roulston, I. Kwan, N. Pepin, J. Lacoste, H. Nguyen, G. Bensi, and M. Fenton. 1993. Characterization of a functional NF- $\mathrm{B}$ site in the human interleukin-1 $\beta$ promoter - evidence for a positive autoregulatory loop. Mol. Cell. Biol. 13:6231-6240.

10. Cogswell, J.P., M.M. Godlevski, G.B. Wisely, W.C. Clay, L.M. Leesnitzer, J.P. Ways, and J.G. Gray. 1994. NF-кB regulates IL-1 $\beta$ transcription through a consensus NF-кB binding site and a nonconsensus CRE-like site. J. Immunol. 153:712-723.

11. Matsusaka, T., K. Fujikawa, Y. Nishio, N. Mukaida, K. Matsushima, T. Kishimoto, and S. Akira. 1993. Transcription factors NF-IL6 and NF-кB synergistically activate transcription of the inflammatory cytokines, interleukin 6 and interleukin 8. Proc. Natl. Acad. Sci. USA. 90:10193-10097.

12. Shibanuma, M., T. Kuroki, and K. Nose. 1994. Inhibition by N-acetylL-cysteine of interleukin- 6 mRNA induction and activation of NF- $\kappa$ B by tumor necrosis factor a in a mouse fibroblastic cell line, Balb/3T3. FEBS Lett. 353:6266.

13. Kunsch, C., and C.A. Rosen. 1993. NF-кB subunit-specific regulation of the interleukin-8 promoter. Mol. Cell. Biol. 13:6137-6146.

14. Oliveira, I.C., N. Mukaida, K. Matsushima, and J. Vilcek. 1994. Transcriptional inhibition of the interleukin- 8 gene by interferon is mediated by the NF-кB site. Mol. Cell. Biol. 14:5300-5308.

15. Ueda, A., K. Okuda, S. Ohno, A. Shirai, T. Igarashi, K. Matsunaga, J. Fukushima, S. Kawamoto, Y. Ishigatsubo, and T. Okubo. 1994. NF-кB and Sp1 regulate transcription of the human monocyte chemoattractant protein-1 gene. J. Immunol. 153:2052-2063.

16. Whelan, J., P. Ghersa, H.R. van Huijsduijnen, J. Gray, G. Chandra, F. Talabot, and J.F. De Lamarter. 1991. An NF-кB-like factor is essential but not sufficient for cytokine induction of endothelial leukocyte adhesion molecule 1 (ELAM-1) gene transcription. Nucleic Acids Res. 19:2645-2653.

17. Shu, H.B., A.B. Agranoff, E.G. Nabel, K. Leung, C.S. Duckett, A.S. Neish, T. Collins, and G.J. Nabel. 1993. Differential regulation of vascular cell adhesion molecule-1 gene expression by specific NF-кB subunits in endothelial and epithelial cells. Mol. Cell. Biol. 13:6283-6289.

18. Neish, A.S., M.A. Read, D. Thanos, R. Pine, T. Maniatis, and T. Collins. 1995. Endothelial interferon regulatory factor 1 cooperates with NF-кB as a transcriptional activator of vascular cell adhesion molecule 1. Mol. Cell. Biol. 15:2558-2569.

19. Voraberger, G., R. Schafer, and C. Stratowa. 1991. Cloning of the human gene for intercellular adhesion molecule 1 and analysis of its $5^{\prime}$-regulatory region. Induction by cytokines and phorbol ester. J. Immunol. 147:2777-2786.

20. Ledebur, H.C., and T.P. Parks. 1995. Transcriptional regulation of the intercellular adhesion molecule-1 gene by inflammatory cytokines in human endothelial cells: essential roles of a variant NF-кB site and p65 homodimers. $J$. Biol. Chem. 270:933-943.

21. Pan, J.L., and R.P. McEver. 1993. Characterization of the promoter for the human P-selectin gene. J. Biol. Chem. 268:22600-22608.

22. Parry, G.C., and N. Mackman. 1995. Transcriptional regulation of tissue factor expression in human endothelial cells. Arteriosclerosis Thromb. Vasc. Biol. 15:612-621.

23. Diaz-Meco, M.T., I. Dominguez, L. Sanz, P. Dent, J. Lozano, M.M. Mu-

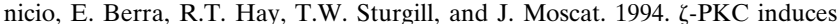
phosphorylation and inactivation of IКB- $\alpha$ in vitro. EMBO J. 13:2842-2848.

24. Miyamoto, S., M. Maki, M.J. Schmitt, M. Hatanaka, and I.M. Verma. 1994. Tumor necrosis factor $\alpha$-induced phosphorylation of IкB- $\alpha$ is a signal for its degradation but not dissociation from NF-кB. Proc. Natl. Acad. Sci. USA. 91:12740-12744.

25. DiDonato, J.A., F. Mercurio, and M. Karin. 1995. Phosphorylation of $\mathrm{I} \kappa \mathrm{B} \alpha$ precedes but is not sufficient for its dissociation from NF-кB. Mol. Cell. Biol. 15:1302-1311.

26. Alkalay, I., A. Yaron, A. Hatzubai, S. Jung, A. Avraham, O. Gerlitz, I. Pashutlavon, and Y. Benneriah. 1995. In vivo stimulation of IкB- $\beta$ phosphorylation is not sufficient to activate NF-кB. Mol. Cell. Biol. 15:1294-1301.

27. Traenckner, E.B.M., H.L. Pahl, T. Henkel, K.N. Schmidt, S. Wilk, and P.A. Baeuerle. 1995. Phosphorylation of human IкB- $\alpha$ on serines 32 and 36

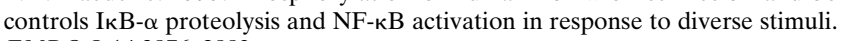
EMBO J. 14:2876-2883.

28. Chen, Z.J., J. Hagler, V.J. Palombella, F. Melandri, D. Scherer, D. Ballard, and T. Maniatis. 1995. Signal-induced site-specific phosphorylation targets
IкB- $\alpha$ to the ubiquitin-proteasome pathway. Genes \& Dev. 9:1586-1597.

29. McElhinny, J.A., S.A. Trushin, G.D. Bren, N. Chester, and C.V. Paya 1996. Casein kinase II phosphorylates IкB- $\alpha$ at S 283, S 289, S 293, and T 291 and is required for its degradation. Mol. Cell. Biol. 16:899-906.

30. DiDonato, J., F. Mercurio, C. Rosette, J. Wuli, H. Suyang, S. Ghosh, and M. Karin. 1996. Mapping of the inducible IкB phosphorylation sites that signal its ubiquitination and degradation. Mol. Cell. Biol. 16:1295-1304.

31. Scherer, D.C., J.A. Brockman, Z.J. Chen, T. Maniatis, and D.W. Ballard. 1995. Signal-induced degradation of IкB- $\alpha$ requires site-specific ubiquitination. Proc. Natl. Acad. Sci. USA. 92:11259-11263.

32. Alkalay, I., A. Yaron, A. Hatzubai, A. Orian, A. Ciechanover, and Y. Benneriah. 1995. Stimulation-dependent IкB- $\alpha$ phosphorylation marks the $\mathrm{NF}-\kappa \mathrm{B}$ inhibitor for degradation via the ubiquitin-proteasome pathway. Proc. Natl. Acad. Sci. USA. 92:10599-10603.

33. Traenckner, E.B.M., and P.A. Baeuerle. 1995. Appearance of apparently ubiquitin-conjugated I $\mathrm{B}-\alpha$ during its phosphorylation-induced degradation in intact cells. J. Cell Sci. Suppl. 19:79-84.

34. Baldi, L., K. Brown, G. Franzoso, and U. Siebenlist. 1996. Critical role for lysines 21 and 22 in signal-induced, ubiquitin-mediated proteolysis of IкB- $\alpha$. J. Biol. Chem. 271:376-379.

35. Chen, Z.J., L. Parent, and T. Maniatis. 1996. Site-specific phosphorylation of IкB $\alpha$ by a novel ubiquitination-dependent protein kinase activity. Cell. 84:853-862.

36. Roff, M., J. Thompson, M.S. Rodriguez, J.M. Jacque, F. Baleux, F. Arenzana-Seisdedos, and R.T. Hay. 1996. Role of ІкB- $\alpha$ ubiquitination in signal-induced activation of NF-кB in vivo. J. Biol. Chem. 271:7844-7850.

37. Mellits, K.H., R.T. Hay, and S. Goodbourn. 1993. Proteolytic degradation of MAD3 $(\mathrm{I} \kappa \mathrm{B} \alpha)$ and enhanced processing of the NF- $\mathrm{B}$ precursor p105 are obligatory steps in the activation of NF-кB. Nucleic Acids Res. 21:50595066.

38. Henkel, T., T. Machleidt, I. Alkalay, M. Kronke, Y. Benneriah, and P.A. Baeuerle. 1993. Rapid proteolysis of IкB- $\alpha$ is necessary for activation of transcription factor NF-кB. Nature (Lond.). 365:182-185.

39. Traenckner, E.B.M., S. Wilk, and P.A. Baeuerle. 1994. A proteasome inhibitor prevents activation of NF- $\mathrm{BB}$ and stabilizes a newly phosphorylated form of IкB- $\alpha$ that is still bound to NF-кB. EMBO J. 13:5433-5441.

40. Brown, K., S. Gerstberger, L. Carlson, G. Franzoso, and U. Siebenlist. 1995. Control of IкB- $\alpha$ proteolysis by site-specific, signal-induced phosphorylation. Science (Wash. DC). 267:1485-1488.

41. Fujita, T., G.P. Nolan, S. Ghosh, and D. Baltimore. 1992. Independent modes of transcriptional activation by the p50 and p65 subunits of NF-кB. Genes \& Dev. 6:775-787.

42. Lin, R.T., D. Gewert, and J. Hiscott. 1995. Differential transcriptional activation in vitro by NF-кB/Rel proteins. J. Biol. Chem. 270:3123-3131.

43. Fujita, T., G.P. Nolan, H.C. Liou, M.L. Scott, and D. Baltimore. 1993 The candidate proto-oncogene bcl-3 encodes a transcriptional coactivator that activates through NF-кB p50 homodimers. Genes \& Dev. 7:1354-1363.

44. Caamano, J.H., P. Perez, S.A. Lira, and R. Bravo. 1996. Constitutive expression of Bcl-3 in thymocytes increases the DNA binding of NF-кB1 (p50) homodimers in vivo. Mol. Cell. Biol. 16:1342-1348.

45. Schmitz, M.L., M.A. dos Santos Silva, H. Altmann, M. Czisch, T.A. Holak, and P.A. Baeuerle. 1994. Structural and functional analysis of the NF-кB p65 C-terminus: an acidic and modular transactivation domain with the potential to adopt an $\alpha$-helical conformation. J. Biol. Chem. 269:25613-25620.

46. Bours, V., V. Azarenko, E. Dejardin, and U. Siebenlist. 1994. Human RelB (I-Rel) functions as a $\kappa \mathrm{B}$ site-dependent transactivating member of the family of Rel-related proteins. Oncogene. 9:1699-1702.

47. Ferran, C., M.T. Millan, V. Csizmadia, J.T. Cooper, C. Brostjan, F.H. Bach, and H. Winkler. 1995. Inhibition of NF-кB by pyrrolidine dithiocarbamate blocks endothelial cell activation. Biochem. Biophys. Res. Commun. 214: 212-223.

48. Brisseau, G.F., A.P.B. Dackiw, P.Y.C. Cheung, N. Christie, and O.D. Rotstein. 1995. Posttranscriptional regulation of macrophage tissue factor expression by antioxidants. Blood. 85:1025-1035.

49. Finco, T.S., A.A. Beg, and A.S. Baldwin. 1994. Inducible phosphoryla-

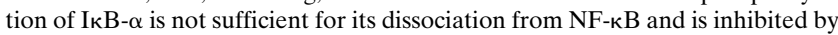
protease inhibitors. Proc. Natl. Acad. Sci. USA. 91:11884-11888.

50. Sun, S.C., J. Elwood, C. Beraud, and W.C. Greene. 1994. Human T cell leukemia virus typeI Tax activation of NF- $\mathrm{B} / \mathrm{Rel}$ involves phosphorylation and degradation of IкB- $\alpha$ and RelA (p65)-mediated induction of the c-rel gene. Mol. Cell. Biol. 14:7377-7384.

51. Read, M.A., A.S. Neish, F.W. Luscinskas, V.J. Palombella, T. Maniatis, and T. Collins. 1995. The proteasome pathway is required for cytokine-induced endothelial-leukocyte adhesion molecule expression. Immunity. 2:493-506.

52. Brostjan, C., J. Anrather, V. Csizmadia, D. Stroka, M. Soares, F.H. Bach, and H. Winkler. 1996. Glucocorticoid-mediated repression of NF-кB activity in endothelial cells does not involve induction of IкB $\alpha$ synthesis. J. Biol. Chem. 271:19612-19617.

53. Wrighton, C.J., R. Hofer-Warbinek, T. Moll, R. Eytner, F.H. Bach, and R. de Martin. 1996. Inhibition of endothelial cell activation by adenovirusmediated expression of $\mathrm{I} \kappa \mathrm{B} \alpha$, an inhibitor of NF-кB. J. Exp. Med. 183:10131022 . 
54. Pan, J.L., and R.P. McEver. 1995. Regulation of the human P-selectin promoter by Bcl-3 and specific homodimeric members of the NF-кB/Rel family. J. Biol. Chem. 270:23077-23083.

55. Kaplan, J.M., J.A. St. George, S.E. Pennington, L.D. Keyes, R.P. Johnson, S.C. Wadsworth, and A.E. Smith. 1996. Humoral and cellular immune responses of nonhuman primates to long-term repeated lung exposure to $\mathrm{Ad} 2 /$ CFTR-2. Gene Ther. 3:117-127.

56. Zabner, J., B.W. Ramsey, D.P. Meeker, M.L. Aitken, R.P. Balfour, R.L. Gibson, J. Launspach, R.A. Moscicki, S.M. Richards, T.A. Standaert, et al. 1996. Repeat administration of an adenovirus vector encoding cystic fibrosis transmembrane conductance regulator to the nasal epithelium of patients with cystic fibrosis. J. Clin. Invest. 97:1504-1511.

57. Ruben, S.M., P.J. Dillon, R. Schreck, T. Henkel, C.H. Chen, M. Maher, P.A. Baeuerle, and C.A. Rosen. 1991. Isolation of a Rel-related human cDNA that potentially encodes the 65-kD subunit of NF-кB. Science (Wash. DC). 254: $11-15$.

58. Evan, G.I., G.K. Lewis, G. Ramsay, and J.M. Bishop. 1985. Isolation of monoclonal antibodies specific for human c-myc proto-oncogene product. Mol. Cell. Biol. 5:3610-3616.

59. Gossen, M., and H. Bujard. 1992. Tight control of gene expression in mammalian cells by tetracycline-responsive promoters. Proc. Natl. Acad. Sci. USA. 89:5547-5551.

60. de Martin, R., B. Vanhove, Q. Cheng, E. Hofer, V. Csizmadia, H. Winkler, and F.H. Bach. 1993. Cytokine-inducible expression in endothelial cells of

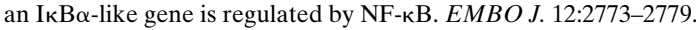

61. Brostjan, C., J. Anrather, V. Csizmadia, G. Natarajan, F.H. Bach, and H. Winkler. 1996. Deletion analysis of the porcine E-selectin promoter. Transplant Proc. 28:649-651.

62. Cooper, J.T., D.M. Stroka, C. Brostjan, A. Palmetshofer, F.H. Bach, and C. Ferran. 1996. A20 blocks endothelial cell activation through a NF-кBdependent mechanism. J. Biol. Chem. 271:18068-18073.

63. de Wet, J.R., K.V. Wood, M. DeLuca, D.R. Helinski, and S. Subramani. 1987. Firefly luciferase gene: structure and expression in mammalian cells. Mol.
Cell. Biol. 7:725-737.

64. Rosenthal, N. 1987. Identification of regulatory elements of cloned genes with functional assays. Methods Enzymol. 152:704-720.

65. Seed, B., and J.Y. Sheen. 1988. A simple phase-extraction assay for chloramphenicol acyltransferase activity. Gene (Amst.). 67:271-277.

66. Subramaniam, M., D. Colvard, P.E. Keeting, K. Rasmussen, B.L. Riggs, and T.C. Spelsberg. 1992. Glucocorticoid regulation of alkaline phosphatase, osteocalcin, and proto-oncogenes in normal human osteoblast-like cells. J. Cell. Biochem. 50:411-424.

67. Dyer, R.B., and N.K. Herzog. 1995. Isolation of intact nuclei for nuclear extract preparation from a fragile B-lymphocyte cell line. Biotechniques. 19 192-195.

68. Leung, K., and G.J. Nabel. 1988. HTLV-1 transactivator induces interleukin-2 receptor expression through an NF-кB-like factor. Nature (Lond.). 333:776-778.

69. Zimmermann, K., M. Dobrovnik, C. Ballaun, D. Bevec, J. Hauber, and E. Böhnlein. 1991. Trans-activation of the HIV-1 LTR by the HIV-1 Tat and HTLV-I Tax proteins is mediated by different cis-acting sequences. Virology. 182:874-878.

70. Gossen, M., S. Freundlieb, G. Bender, G. Müller, W. Hillen, and H. Bujard. 1995. Transcriptional activation by tetracyclines in mammalian cells. Science (Wash. DC). 268:1766-1769.

71. Furth, P.A., L. Stonge, H. Boger, P. Gruss, M. Gossen, A. Kistner, H. Bujard, and L. Hennighausen. 1994. Temporal control of gene expression in transgenic mice by a tetracycline-responsive promoter. Proc. Natl. Acad. Sci. USA. 91:9302-9306.

72. Cheng, Q., C.A. Cant, T. Moll, R. Hofer-Warbinek, E. Wagner, M.L. Birnstiel, F.H. Bach, and R. de Martin. 1994. NF-кB subunit-specific regulation of the IкB $\alpha$ promoter. J. Biol. Chem. 269:13551-13557.

73. Beg, A.A., W.C. Sha, R.T. Bronson, S. Ghosh, and D. Baltimore. 1995. Embryonic lethality and liver degeneration in mice lacking the RelA component of NF-кB. Nature (Lond.). 376:167-170. 